\title{
PENGARUH STRUKTUR AUDIT, KONFLIK PERAN DAN KETIDAKJELASAN PERAN TERHADAP KINERJA AUDITOR
}

\author{
Haryani Anggraeni ${ }^{1}$ \\ Imam Hadiwibowo ${ }^{2}$ \\ ${ }^{1}$ Fakultas Ekonomi, Universitas Muhammadiyah Cirebon \\ Email : haryanianggraeni99@gmail.com \\ ${ }^{2}$ Fakultas Ekonomi, Universitas Muhammadiyah Cirebon \\ Email : imam.hadiwibowo@umc.ac.id
}

\begin{abstract}
Abstrak
Kinerja auditor menjadi perhatian utama, baik bagi klien ataupun publik, dalam menilai hasil audit yang dilakukan. Kinerja auditor merupakan hasil kerja yang dicapai oleh auditor dalam melaksanakan tugasnya, sesuai dengan tanggung jawab yang diberikan padanya dan menjadi salah satu tolak ukur yang digunakan untuk menentukan, apakah suatu pekerjaan yang dilakukan akan baik atau sebaliknya. Kondisi kerja yang kurang kondusif mempengaruhi kinerja auditor sehingga dapat mempengaruhi kepercayaan masyarakat terhadap akuntan publik sebagai pihak yang independen dalam mengaudit laporan keuangan. Tujuan yang ingin dicapai di dalam penelitian ini adalah untuk mengetahui pengaruh struktur audit, konflik peran dan ketidakjelasan peran terhadap kinerja auditor pada Kantor Akuntan Publik yang terdaftar di IAPI Cabang Bandung. Metode penelitian yang digunakan dalam penelitian ini adalah metode survey. Hasil penelitian ini yaitu struktur audit (X1) mempunyai pengaruh yang signifikan terhadap kinerja auditor (Y).
\end{abstract}

Kata Kunci : Struktur Audit, Konflik Peran dan Ketidakjelasan Peran

\section{PENDAHULUAN}

Kantor akuntan publik merupakan sebuah organisasi yang bergerak di bidang jasa. Profesional akuntan publik sebagai pihak yang dianggap independen, menuntut profesi akuntan publik untuk meningkatkan kinerjanya agar dapat menghasilkan produk audit yang dapat diandalkan bagi pihak yang membutuhkan. Kinerja auditor menjadi perhatian utama, baik bagi klien ataupun publik, dalam menilai hasil audit yang dilakukan. Kinerja auditor merupakan hasil kerja yang dicapai oleh auditor dalam melaksanakan tugasnya, sesuai dengan tanggung jawab yang diberikan padanya dan menjadi salah satu tolak ukur yang digunakan untuk menentukan, apakah suatu pekerjaan yang dilakukan akan baik atau sebaliknya.

Kondisi kerja yang kurang kondusif mempengaruhi kinerja auditor, sehingga dapat mempengaruhi kepercayaan masyarakat terhadap akuntan publik sebagai pihak yang independen dalam pengauditan laporan keuangan. Skandal akuntansi perusahaan-perusahaan besar di Amerika seperti Enron, Global Crossing, Worldcom, Microstrategy, Adelphia, PNC Financial Service dan Rite Aid hampir semuanya melibatkan Kantor Akuntan Publik besar seperti The Big Five. KAP kelas menengah juga tidak luput dari masalah tersebut, seperti RSM Salustro Reydel di Prancis yang melakukan kesalahan saat melakukan audit atas Vivendi Universal.

Gambaran terhadap pengaruh struktur audit, konflik peran dan ketidakjelasan peran terhadap kinerja auditor seperti yang dikemukakan oleh Fisher (2001) hasil penelitian menunjukkan bahwa baik konflik peran dan ketidakjelasan peran berpengaruh negatif terhadap kinerja auditor. Namun ada beberapa penelitian yang menyatakan berbeda bahwa ketidakjelasan peran tidak berpengaruh terhadap kinerja auditor. Zaenal Fanani dkk (2007) dalam penelitiannya menunjukkan bahwa ketidakjelasan peran yang muncul karena tidak cukupnya informasi yang diperlukan untuk menyelesaikan tugas-tugas atau pekerjaan yang dirasakan auditor belum tentu dapat menurunkan kinerja mereka. Viator (2001) Zaenal Fanani dkk (2007), hasil penelitian tersebut menunjukkan bahwa konflik peran berpengaruh terhadap kinerja dan kepuasan kerja sedangkan ketidakjelasan peran tidak berpengaruh terhadap kinerja hanya mempengaruhi kepuasan kerja akuntan. 
Pada dasarnya penelitian ini merupakan replikasi dari penelitian yang dilakukan oleh Zaenal Fanani dkk. (2007). Alasannya karena pertama, adanya kontradiktif dari hasil penelitian terdahulu, dan kedua, adanya perbedaan objek penelitian ini dengan penelitian sebelumnya yaitu pada Kantor Akuntan Publik (KAP) yang terdaftar di IAPI Cabang Jakarta, Sehingga hal tersebut menarik untuk dikaji kembali oleh penulis dan ingin membuktikan kembali secara empiris seberapa besar faktor yang memiliki pengaruh paling dominan terhadap kinerja auditor dari struktur audit, konflik peran, dan ketidakjelasan peran sesuai dengan yang direkomendasikan Zaenal Fanani dkk (2007).

\section{Kajian Pustaka}

\section{Teori Tujuan (Goal Theory)}

Teori ini mula-mula dikembangkan oleh Locke (1968) dalam Hudayati (2002). Teori ini mengemukakan bahwa perilaku seseorang ditentukan oleh dua cognitions yaitu values dan intentions (atau tujuan). Yang dimaksud dengan values adalah apa yang dihargai sese- orang sebagai upaya mendapatkan kemakmuran/welfare. Orang telah menentukan goal atas perilakunya di masa depan dan goal tersebut akan memengaruhi perilaku yang sesungguhnya. Teori ini juga menyatakan bahwa perilaku individu diatur oleh ide (pemikiran) dan niat seseorang. Sasaran dapat dipandang sebagai tujuan/tingkat kinerja yang ingin dicapai oleh individu. Jika seorang individu komit dengan sasaran tertentu, maka hal ini akan memengaruhi tindakannya dan memengaruhi konsekuensi kinerjanya.

\section{Teori Stewardship}

Teori stewardship adalah teori yang menggambarkan situasi dimana para manajer tidaklah termotivasi oleh tujuan-tujuan individu tetapi lebih ditujukan pada sasaran hasil utama mereka untuk kepentingan organisasi, sehingga teori ini mempunyai dasar psikologi dan sosiologi yang telah dirancang dimana para eksekutif sebagai steward termotivasi untuk bertindak sesuai keinginan prinsipal, selain itu perilaku steward tidak akan meninggalkan organisasinya sebab steward berusaha mencapai sasaran organisasinya. Teori ini didesain bagi para peneliti untuk menguji situasi dimana para eksekutif dalam perusahaan sebagai pelayan dapat termotivasi untuk bertindak dengan cara terbaik pada principalnya (Donaldson dan Davis, 1989 dalam Mardiasno, 2002).

\section{Kerangka Pemikiran}

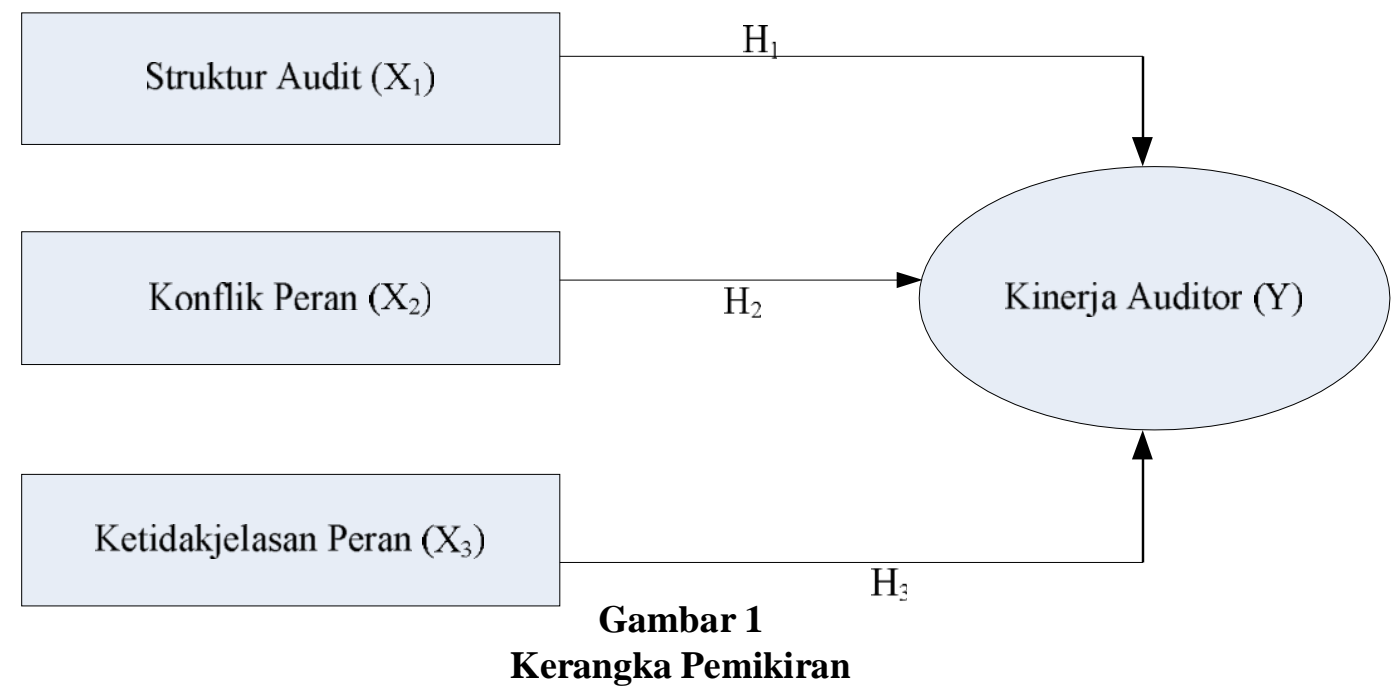

\section{Hipotesis}

Berdasarkan kesimpulan tersebut dapat dirumuskan hipotesis sebagai berikut:

$\mathrm{H}_{1}$ : Struktur audit berpengaruh terhadap kinerja auditor.

$\mathrm{H}_{2}$ : Konflik peran berpengaruh terhadap kinerja auditor.

$\mathrm{H}_{3}$ : Ketidakjelasan peran tidak berpengaruh terhadap kinerja auditor. 


\section{Metode Penelitian}

\section{Jenis Penelitian}

Penelitian ini menggunakan metode penelitian asosiatif. Menurut Arikunto (2001) pengertian asosiatif adalah: "Penelitian asosiatif adalah penelitian yang bertujuan untuk mengetahui hubungan antara dua variabel atau lebih." Penelitian ini merupakan jenis penelitian dengan metode confirmatory research dengan pendekatan kuantitatif. "Confirmatory research adalah penelitian yang memiliki tujuan untuk menguji kembali hasil penelitian terdahulu dan mencari pembenaran atas kontradiktif dari hasilhasil penelitan terdahulu". (Arikunto, 2001).

\section{Lokasi dan Waktu Penelitian}

Penelitian ini dilakukan pada auditor di Kantor Akuntan Publik yang terdaftar di IAPI Cabang Bandung dari Maret 2016 sampai dengan Agustus 2016. Alasan penelitian ini dilakukan pada KAP yang terdaftar di IAPI Cabang Bandung karena di jawa barat jumlah KAP terbanyak kedua adalah IAPI Cabang Bandung sedangkan jumlah KAP terbanyak pertama adalah KAP yang terdaftar di IAPI Cabang Jakarta sudah pernah diteliti sebelumnya.

\section{Populasi dan Sampel}

Menurut Arikunto (2001) mendefinisikan populasi yaitu "Populasi adalah wilayah generalisasi yang terdiri atas objek/ subjek yang mempunyai kualitas dan karakter tertentu yang diharapkan oleh peneliti untuk dipelajari dan kemudian ditarik kesimpulannya." Populasi dalam penelitian ini adalah seluruh auditor pada Kantor Akuntan Publik (KAP) yang terdaftar di IAPI Cabang Bandung karena pada penelitian terdahulu populasi yang digunakan adalah KAP yang terdaftar di IAPI Cabang Jakarta, dengan jumlah populasi yang menjadi dasar penelitian adalah jumlah auditor di 30 Kantor Akuntan Publik yang terdaftar di IAPI Cabang Bandung tahun 2015. Menurut Arikunto (2002) mendefinisikan sampel yaitu : "Sampel adalah sebagian atau wakil populasi yang diteliti". Sampel penelitian ini yaitu para auditor yang bekerja di Kantor Akuntan Publik yang terdaftar di IAPI Cabang Bandung. Karena menggunakan sampel, maka peneliti hanya mengambil sampel penelitian sebanyak 30 responden dari setiap Kantor Akuntan Publik yang terdaftar di IAPI Cabang Bandung.

\section{Sumber Data}

Sebagian besar tujuan penelitian adalah untuk memperoleh data yang relevan, dapat dipercaya dan dapat dipertanggung jawabkan. Dalam penyusunan Penelitian ini penulis memperoleh sumber-sumber data yang merupakan data primer. Data primer merupakan data yang sumber informasinya diperoleh melalui pengawasan langsung pada instansi yang menjadi objek penelitian dengan cara kuesioner.

\section{Teknik Pengumpulan Data}

Metode pengumpulan data yang digunakan untuk memperoleh data-data yang diperlukan dalam penulisan Penelitian ini adalah sebagai berikut:

\section{Metode Studi Kepustakaan}

Yaitu studi yang dilaksanakan untuk memperoleh masukan, konsep, prinsip, teori atau hukumhukum yang berlaku dalam bidang penelitian yang ada kaitannya dengan permasalahan yang dikaji, diperoleh data primer.

\section{Metode Lapangan}

Metode ini dilakukan dengan cara peninjauan langsung pada Kantor Akuntan Publik yang akan diteliti untuk memperoleh data primer. Data primer dapat diperoleh melalui kuesioner, yaitu dengan mengajukan daftar pernyataan dalam bentuk tertulis yang berhubungan dengan masalah yang diteliti kepada responden dalam hal ini yaitu para auditor. 


\section{Definisi Operasional}

Tabel 1. Definisi Operasional Variabel

\begin{tabular}{|c|l|l|}
\hline No & \multicolumn{1}{|c|}{ Variabel } & \multicolumn{1}{c|}{ Definisi } \\
\hline 1 & $\begin{array}{l}\text { Kinerja auditor } \\
(Y)\end{array}$ & $\begin{array}{l}\text { Hasil kerja yang dicapai oleh seseorang dalam } \\
\text { melaksanakan tugasnya, sesuai dengan tanggung } \\
\text { jawab yang diberikan padanya dan menjadi salah satu } \\
\text { tolak ukur yang digunakan untuk menentukan apakah } \\
\text { suatu pekerjaan yang dilakukan akan baik ataukah } \\
\text { sebaliknya. }\end{array}$ \\
\hline 2 & $\begin{array}{l}\text { Struktur audit } \\
\left(\mathrm{X}_{1}\right)\end{array}$ & $\begin{array}{l}\text { Sebuah pendekatan sistematis, terhadap auditing yang } \\
\text { dikarakteristikkan oleh langkah-langkah penentuan } \\
\text { audit, prosedur / rangkaian logis, keputusan, } \\
\text { dokumentasi, dan menggunakan sekumpulan alat-alat } \\
\text { dan kebijakan audit yang komprehensif dan } \\
\text { terintegrasi untuk membantu auditor melakukan audit. }\end{array}$ \\
\hline 3 & $\begin{array}{l}\text { Konflik peran } \\
\left(\mathrm{X}_{2}\right)\end{array}$ & $\begin{array}{l}\text { Suatu gejala psikologis yang dialami oleh anggota } \\
\text { organisasi yang bisa menimbulkan rasa tidak nyaman } \\
\text { dalam bekerja }\end{array}$ \\
\hline 4 & $\begin{array}{l}\text { Ketidakjelasan } \\
\text { peran }\left(\mathrm{X}_{3}\right)\end{array}$ & $\begin{array}{l}\text { Tidak cukupnya informasi yang dimiliki serta tidak } \\
\text { adanya arah dan kebijakan yang jelas, ketidakpastian } \\
\text { tentang otoritas, kewajiban dan hubungan dengan } \\
\text { lainnya, dan ketidakpastian sanksi dan ganjaran } \\
\text { terhadap perilaku yang dilakukan }\end{array}$ \\
\hline
\end{tabular}

\section{PENELITIAN HASIL DAN PEMBAHASAN}

\section{Gambaran Umum Responden}

Karakteristik responden dalam penelitian ini sangat beragam. Responden yang diteliti oleh peneliti adalah auditor di Kantor Akuntan Publik yang terdaftar di IAPI Cabang Bandung. Dalam pembahasan ini, karakteristik responden disajikan dalam presentase. Dari 30 responden yang memberikan jawaban penelitian / kuesioner dapat diketahui perbedaan karakteristik antara responden yang satu dengan yang lainnya. Perbedaan ini meliputi jenis kelamin, jabatan di Kantor Akuntan Publik, lama bekerja di Kantor Akuntan Publik, dan lama menjadi auditor.

\section{Uji Validitas dan Reliabilitas}

Suatu instrumen dapat dikatakan valid apabila telah melalui suatu uji coba. Semakin valid instrument, maka akan semakin valid pula data yang didapatkan. Dalam hal ini, instrumen yang digunakan adalah angket kuesioner. Selanjutnya, peneliti melakukan uji validitas berdasarkan formula tertentu, diantaranya koefisien korelasi product moment dari Karl Pearson, yaitu (Arikunto, 2001) :

$$
\operatorname{rxy}=\frac{N \sum x y-\left(\sum x\right)\left(\sum y\right)}{\sqrt{N \sum^{2}-\left(\sum x\right)^{2} N \sum y^{2}-\left(\sum y\right)^{2}}}
$$

Dimana :

$$
\begin{array}{ll}
\mathrm{rxy} & =\text { Koefsien korelasi pearson product moment } \\
\mathrm{N} & =\text { Jumlah sampel } \\
\Sigma \mathrm{x} & =\text { Jumlah skor total } \\
\Sigma \mathrm{xy} & =\text { Jumlah perkalian skor butir dengan skor total } \\
\Sigma \mathrm{x}^{2} & =\text { Jumlah kuadrat skor butir } \\
\Sigma \mathrm{y}^{2} & =\text { Jumlah kuadrat skor total }
\end{array}
$$


Kriteria pengujian adalah sebagai berikut :

Jika $r_{x y}$ hitung > rtabel, maka pernyataan dinyatakan valid

Jika $r_{x y}$ hitung < rtabel, maka pernyataan dinyatakan tidak valid

Pengolahan data dilakukan dengan menggunakan komputer (program SPSS = Statistical Package for Sosial Science) for Windows 17.0, dan menghasilkan nilai rhitung tiap item, dapat disimpulkan bahwa semua item dari variabel struktur audit, konflik peran, ketidakjelasan peran dan kinerja auditor adalah signifikan, sebab rhitung $\geq$ rtabel. Dengan demikian, semua item pertanyaan angket dapat dikatakan valid dan dapat digunakan untuk analisis data berikutnya. Pengujian berikutnya adalah uji reliabilitas. Uji reliabilitas dilakukan untuk mengetahui konsistensi dari instrumen yang digunakan sebagai alat ukur. Peneliti dalam hal ini menggunakan uji reliabilitas dengan formula Koefisien Alfa ( $\alpha$ ) dari Cronbanch, yaitu (Arikunto, 2001):

$$
r_{11}=\left[\frac{k}{(k-1)}\right]\left[1-\frac{\sum \sigma_{b}^{2}}{\sigma_{t}^{2}}\right]
$$

Dimana :

$\mathrm{r} 11=$ Reliabilitas instrumen / koefisien alfa

$\mathrm{k}=$ Banyaknya butir soal

$\sum \sigma_{b}^{2}=$ Jumlah varian total

$\sigma_{t}^{2}=$ Varian total

Pengolahan data selanjutnya dilakukan dengan komputer berbasis pada SPSS for windows 17.0 dan diperoleh hasil bahwa rhitung untuk variabel struktur audit sebesar 0,609 dan rabel sebesar 0,6 maka dapat dinyatakan bahwa instrumen variabel struktur audit mempunyai tingkat reliabel yang tinggi. Konflik peran sebesar 0,669 dan rtabel sebesar 0,6 maka dapat dinyatakan bahwa instrumen variabel konflik peran mempunyai tingkat reliabel yang tinggi. Ketidakjelasan peran sebesar 0,836 dan rtabel sebesar 0.6 maka dapat dinyatakan bahwa instrumen variabel ketidakjelasan peran mempunyai tingkat reliabel yang sangat tinggi. Kinerja auditor sebesar 0,785 dan rtabel sebesar 0,6 maka dapat dinyatakan bahwa instrumen variabel kinerja auditor mempunyai tingkat reliabel yang tinggi, dapat disimpulkan bahwa variabel struktur audit, konflik peran dan kinerja auditor mempunyai tingkat reliabel yang tinggi, sedangkan variabel kinerja auditor mempunyai tingkat reliabel yang sangat tinggi.

\section{Uji Asumsi Klasik \\ Uji Normalitas}

Uji normalitas dilakukan dengan menggunakan analisis Kolmogorof Smirnov. Batas kritis untuk uji normalitas adalah apabila nilai Asymp.Sig (2 tailed) lebih dari $\alpha$. Dari analisis menggunakan SPSS for Windows 17.0 di dapat nilai Asymp.Sig (2 tailed) lebih dari $\alpha=5 \%$. Oleh karena itu distribusi data normal, dan artinya asumsi normalitas dalam analisis ini terpenuhi.

\section{Multikolinearitas}

Uji multikolinearitas dimaksudkan untuk menentukan apakah diantara variabel bebas terjadi korelasi. Pengujian ini dilakukan dengan melihat nilai Variance Inflation Faktor (VIF) dari setiap variabel bebas terhadap variabel terikat. Jika nilai VIF tidak lebih besar dari 10, maka dalam model tidak terjadi multikolinearitas. Dari analisis menggunakan SPSS for Windows 17.0 didapat nilai VIF untuk masing-masing variabel bebas sebesar 3,031, 1,971 dan 3,474 yang lebih kecil dari 10. Oleh karena itu tidak terjadi multikolinearitas, dan artinya asumsi multikolinearitas dalam analisis ini terpenuhi. 


\section{Heteroskedastisitas}

Adanya heteroskedastisitas menunjukkan adanya varian variabel dalam model yang tidak sama (konstan). Untuk mendeteksi gejala ini digunakan metode Park Gleyser. Model regresi dikatakan tidak terjadi heteroskedastisitas apabila $t$ hitung $<\mathrm{t}$ tabel atau Sig.t $>\square$.

Tabel 2.

\section{Uji Heteroskedastisitas \\ Coefficients $^{\mathrm{a}}$}

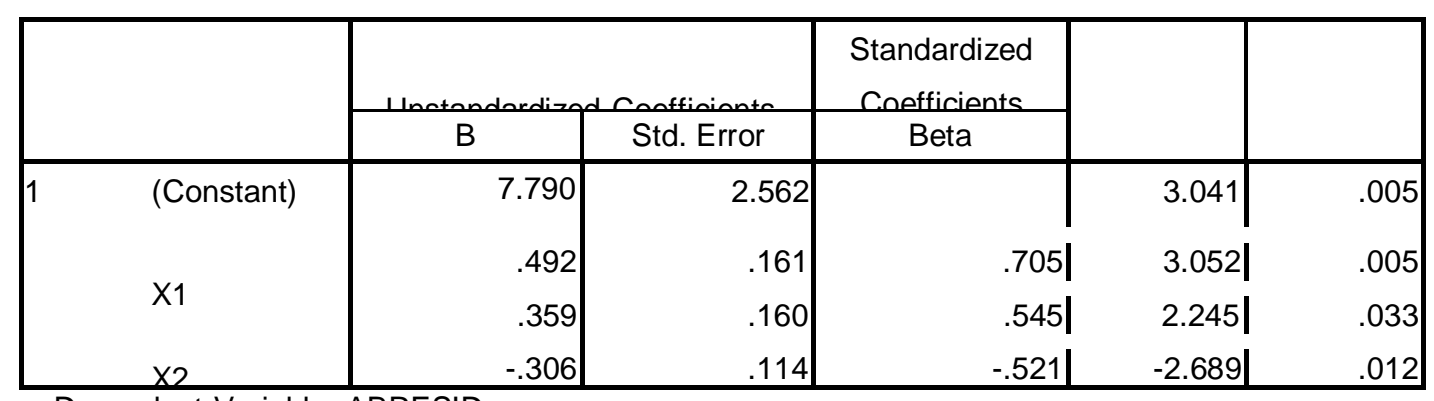

a. Dependent Variable: ABRESID

Dari analisis menggunakan SPSS for Windows 17.0 dapat diketahui bahwa pada model tidak terjadi gejala heteroskedastisitas.

\section{Linearitas}

Pengujian ini diperlukan untuk mengetahui bahwa model yang diuji merupakan model linear. Untuk menguji linearitas adalah dengan menggunakan MWD test. Dengan menggunakan MWD tes ini, model dikatakan linear jika nilai sig-t untuk Z1 lebih dari $\alpha=5 \%$ dari analisis menggunakan SPSS for Windows 17,0 dapat diketahui bahwa nilai sig-t untuk Z1. = 0,879 lebih dari $\alpha=5 \%$.

\section{Pengujian Model / Uji F}

Untuk menguji secara bersama-sama pengaruh faktor struktur audit, konflik peran dan ketidakjelasan peran terhadap kinerja auditor digunakan uji F dengan rumus (Arikunto, 2001) :

$$
\begin{aligned}
& \mathrm{F}=\frac{R^{2} / k}{1-R^{2}(n-k-1)} \\
& \text { Dimana : } \\
& \mathrm{F}=\text { Nilai Fhitung } \\
& \mathrm{R}^{2}=\text { Koefisien korelasi ganda } \\
& \mathrm{K}=\text { Jumlah variabel bebas } \\
& \mathrm{n}=\text { Jumlah sampel }
\end{aligned}
$$

Statistik uji di atas mengikuti distribusi F-snecdor dengan derajat kebebasan $\mathrm{vl}=\mathrm{k}$ dan $\mathrm{v} 2=$ $\mathrm{n}-\mathrm{k}-\mathrm{l}$, pengujian dilakukan dengan tingkat keyakinan $95 \%(\alpha=0,05)$.

Kriteria pengujian hipotesis:

Jika Ftes > Ftabel, maka Ho ditolak yang berarti variabel struktur audit, konflik peran dan ketidakjelasan peran mempunyai pengaruh yang signifikan terhadap kinerja auditor. Jika Ftes < Ftabel, maka Ho diterima yang berarti variabel struktur audit, konflik peran dan ketidakjelasan peran tidak mempunyai pengaruh yang signifikan terhadap kinerja auditor. 
Berdasarkan hasil perhitungan dengan menggunakan Program SPSS for Windows 17.0, diperoleh nilai Fhitung sebagai berikut:

Tabel 3.

Uji F

ANOVA $^{\mathrm{a}}$

\begin{tabular}{|rl|r|r|r|r|r|}
\hline Model & & Sum of Squares & df & Mean Square & F & Sig. \\
\hline \multirow{2}{*}{1} & Regression & 500.815 & 3 & 166.938 & 35.187 & $.000^{\mathrm{b}}$ \\
& Residual & 123.352 & 26 & 4.744 & & \\
& Total & 624.167 & 29 & & & \\
\end{tabular}

a. Dependent Variable: $y$

b. Predictors: (Constant), $x 3, \times 2, x 1$

Berdasarkan hasil tersebut didapat Fhitung sebesar 35.187. Sedangkan Ftabel dengan derajat kebebasan $\mathrm{v} 1=\mathrm{k}$ dan $\mathrm{v} 2=\mathrm{n}-\mathrm{k}-1$ dan dengan tingkat keyakinan 95\% $(\square=0,05)$ diperoleh $\mathrm{F}_{\text {tabel }}$ sebesar 2,920. Dengan demikian nilai Fhitung lebih besar dari Ftabel (35,187 > 2,920). Dengan demikian dapat dikatakan bahwa variabel struktur audit (X1), konflik peran ( $\left.\mathrm{X}_{2}\right)$ dan ketidakjelasan peran (X3) mempunyai pengaruh bersama, artinya ketiga variabel tersebut selalu mempengaruhi kinerja auditor pada Kantor Akuntan Publik yang terdaftar di IAPI Cabang Bandung. Dengan kata lain dapat dikatakan secara serentak variasi ketiga variabel bebas mampu menjelaskan variasi variabel terikatnya yaitu kinerja auditor pada Kantor Akuntan Publik yang terdaftar di IAPI Cabang Bandung. Dapat dikatakan pula bahwa ketiga variabel bebas tersebut dapat menjelaskan model yang digunakan dalam penelitian ini

Untuk mengetahui seberapa besar pengaruh struktur audit, konflik peran dan ketidakjelasan peran terhadap kinerja auditor dapat dilihat dari nilai R square. Dari tabel Model Summary di bawah ini terlihat bahwa angka $\mathrm{R}^{2}$ adalah 0,802 , hal ini berarti bahwa 80,2 persen kinerja auditor dapat dijelaskan oleh variabel struktur audit, konflik peran dan ketidakjelasan peran sedangkan sisanya 19,8 persen dijelaskan oleh sebab- sebab lain yang tidak diteliti.

\section{Uji Hipotesis / Uji t}

Pengujian secara parsial dilakukan dengan menggunakan uji-t, dengan rumus sebagai berikut:

$$
\mathrm{t}_{\text {hit }}=\frac{\mathrm{b}}{\mathrm{Sb}}
$$

Dimana :

Thit $=$ tes regresi

$\mathrm{b} \quad=$ koefisien regresi parsial

$\mathrm{Sb} \quad=$ Standar error koefisien

Kriteria pengujian hipotesis :

$\mathrm{H}_{0}$ : variabel struktur audit, konflik peran dan ketidakjelasan peran tidak mempunyai pengaruh yang signifikan terhadap kinerja auditor.

$\mathrm{H}_{\mathrm{a}} \quad$ : variabel struktur audit, konflik peran dan ketidakjelasan peran mempunyai pengaruh yang signifikan terhadap kinerja auditor.

Dengan derajat kebebasan $(\mathrm{df})=\mathrm{n}-\mathrm{k}-1$ dan tingkat keyakinan 95\% $(\alpha=0,05)$ maka :

Ho diterima jika -ttabel $\leq$ thitung $\leq$ ttable

Ho ditolak jika thitung $>$ tabel 
Berdasarkan hasil perhitungan dengan menggunakan Program SPSS for Windows 17.0, diperoleh nilai t hitung sebagai berikut :

\section{Tabel 4 \\ Uji t \\ Coefficients $^{\mathrm{a}}$}

\begin{tabular}{|c|c|c|c|c|c|}
\hline \multirow[t]{2}{*}{ Model } & \multicolumn{2}{|l|}{ Coefficients } & \multirow{2}{*}{$\begin{array}{l}\text { Standardized } \\
\text { Coefficients } \\
\text { Beta }\end{array}$} & \multirow[t]{2}{*}{$\mathrm{t}$} & \multirow[t]{2}{*}{ Sig. } \\
\hline & B & Std. Error & & & \\
\hline (Constant) & -1.927 & 2.665 & & -.723 & .476 \\
\hline $\mathrm{x} 1$ & .547 & .233 & .356 & 2.346 & .027 \\
\hline$x 2$ & .809 & .150 & .661 & 5.401 & .000 \\
\hline$x 3$ & -.055 & .216 & -.041 & -.253 & .802 \\
\hline
\end{tabular}

a. Dependent Variable: $y$

Dengan menggunakan tingkat keyakinan sebesar 95\% $(\square=0.05)$ dan derajat kebebasan ( $\mathrm{n}-\mathrm{k}-$ 1) diperoleh tabel sebesar 1,700. Dari tabel di atas terlihat bahwa thitung untuk variabel struktur audit (X1) sebesar 2,346. Jadi nilai thitung variabel adalah lebih besar dari tabel $(2,346>1,700)$, sehingga secara parsial variabel struktur audit mempunyai pengaruh terhadap kinerja auditor pada Kantor Akuntan Publik yang terdaftar di IAPI Cabang Bandung.

\section{Hipotesis Pertama}

Dengan menggunakan tingkat keyakinan sebesar 95\% $(\square=0.05)$ dan derajat kebebasan $(\mathrm{n}-\mathrm{k}-$ 1) diperoleh tabel sebesar 1,700. Dari tabel di atas terlihat bahwa thitung untuk variabel konflik peran $\left(\mathrm{X}_{2}\right)$ sebesar 5,401. Jadi nilai thitung variabel adalah lebih besar dari tabel (5,401 > 1,700), sehingga secara parsial variabel konflik peran mempunyai pengaruh terhadap kinerja auditor pada Kantor Akuntan Publik yang terdaftar di IAPI Cabang Bandung.

\section{Hipotesis Kedua}

Dengan menggunakan tingkat keyakinan sebesar 95\% $(\square=0.05)$ dan derajat kebebasan $(\mathrm{n}-\mathrm{k}-$ 1) diperoleh tabel sebesar 1,700. Dari tabel di atas terlihat bahwa thitung untuk variabel ketidakjelasan peran $\left(\mathrm{X}_{3}\right)$ sebesar $-0,253$. Jadi nilai thitung variabel adalah lebih kecil dari tabel $(-0.253<1,700)$, sehingga secara parsial variabel ketidakjelasan peran tidak mempunyai pengaruh terhadap kinerja auditor pada Kantor Akuntan Publik yang terdaftar di IAPI Cabang Bandung.

\section{Hipotesis Ketiga}

Untuk mengetahui variabel manakah diantara struktur audit $\left(\mathrm{X}_{1}\right)$ dan konflik peran $\left(\mathrm{X}_{2}\right)$ yang paling berpengaruh terhadap kinerja auditor (Y), adalah dengan melihal tabel di atas pada kolom beta. Dari tabel tersebut terlihat bahwa Beta untuk variabel struktur audit (X1) sebesar 0,356 dan konflik peran $\left(\mathrm{X}_{2}\right)$ sebesar 0,661 dengan demikian jelas bahwa variabel struktur audit (X1) adalah merupakan variabel yang paling berpengaruh terhadap kinerja auditor pada Kantor Akuntan Publik yang terdaftar di IAPI Cabang Bandung.

\section{PEMBAHASAN}

\section{Pengaruh Struktur Audit terhadap Kinerja Auditor}

Dengan menggunakan tingkat keyakinan sebesar 95\% $(\square=0.05)$ dan derajat kebebasan $(\mathrm{n}-\mathrm{k}$ - 1) diperoleh tabel sebesar 1,700. Dari tabel di atas terlihat bahwa thitung untuk variabel struktur audit (X1) sebesar 2,346. Jadi nilai thitung variabel adalah lebih besar dari tabel $(2,346>1,700)$, sehingga secara parsial variabel struktur audit mempunyai pengaruh terhadap kinerja auditor pada 
Kantor Akuntan Publik yang terdaftar di IAPI Cabang Bandung. Hasil ini mendukung penelitian Zaenal Fanani (2007) bahwa struktur audit bepengaruh signifikan terhadap kinerja auditor. Secara lebih spesifik lagi Zaenal Fanani dkk (2007) menyatakan bahwa struktur audit adalah: "Sebuah pendekatan sistematis terhadap auditing yang dikarakteristikkan oleh langkah-langkah penentuan audit, prosedur rangkaian logis, keputusan, dokumentasi, dan menggunakan sekumpulan alat-alat dan kebijakan audit yang komprehensif dan terintegrasi untuk membantu auditor melakukan audit. Secara lebih spesifik lagi Zaenal Fanani dkk (2007) menyatakan bahwa kinerja auditor adalah: "kinerja auditor merupkan hasil kerja yang dicapai oleh seseorang dalam melaksanakan tugasnya, sesuai dengan tanggung jawab yang diberikan padanya dan menjadi salah satu tolak ukur yang digunakan untuk menentukan apakah suatu pekerjaan yang dilakukan akan baik ataukah sebaliknya". Dengan demikian struktur audit merupakan faktor penentu untuk meningkatkan kinerja auditor. Hal ini menunjukan bahwa penggunaan struktur audit dapat membantu auditor dalam melaksanakan tugasnya menjadi lebih baik sehingga dapat meningkatkan kinerja auditor.

\section{Pengaruh Konflik Peran terhadap Kinerja Auditor}

Dengan menggunakan tingkat keyakinan sebesar 95\% $(\square=0.05)$ dan derajat kebebasan $(\mathrm{n}-\mathrm{k}$ - 1) diperoleh tabel sebesar 1,700. Dari tabel di atas terlihat bahwa thitung untuk variabel konflik peran $\left(\mathrm{X}_{2}\right)$ sebesar 5,401. Jadi nilai thitung variabel adalah lebih besar dari tabel (5,401 > 1,700), sehingga secara parsial variabel konflik peran mempunyai pengaruh terhadap kinerja auditor pada Kantor Akuntan Publik yang terdaftar di IAPI Cabang Bandung. Hasil ini mendukung penelitian Zaenal Fanani (2007) bahwa konflik peran bepengaruh signifikan terhadap kinerja auditor. Menurut P. Robinson (2008) bahwa konflik adalah : "Konflik merupakan sebuah proses yang dimulai ketika satu pihak memiliki persepsi bahwa pihak lain telah mempengaruhi secara negatif, atau akan mempengaruhi secara negatif, sesuatu yang menjadi perhatian dan kepentingan pihak pertama". Secara lebih spesifik lagi Zaenal Fanani dkk (2007) menyatakan bahwa kinerja auditor adalah: "kinerja auditor merupkan hasil kerja yang dicapai oleh seseorang dalam melaksanakan tugasnya, sesuai dengan tanggung jawab yang diberikan padanya dan menjadi salah satu tolak ukur yang digunakan untuk menentukan apakah suatu pekerjaan yang dilakukan akan baik ataukah sebaliknya"Dengan demikian konflik peran merupakan faktor penentu untuk meningkatkan kinerja auditor. Hal ini menunjukan bahwa konflik peran yang merupakan suatu gejala psikologis yang dialami oleh auditor yang timbul karena adanya dua rangkaian tuntutan yang bertentangan sehingga menyebabkan rasa tidak nyaman dalam bekerja dan secara potensial bisa menurunkan motivasi kerja sehingga bisa menurunkan kinerja secara keseluruhan.

\section{Pengaruh Ketidakjelasan Peran terhadap Kinerja Auditor}

Dengan menggunakan tingkat keyakinan sebesar $95 \%(\square=0.05)$ dan derajat kebebasan $(\mathrm{n}-\mathrm{k}$ - 1) diperoleh tabel sebesar 1,700. Dari tabel di atas terlihat bahwa thitung untuk variabel ketidakjelasan peran (X3) sebesar -0,253. Jadi nilai thitung variabel adalah lebih kecil dari tabel ($0,253<1,700)$, sehingga secara parsial variabel ketidakjelasan peran tidak mempunyai pengaruh terhadap kinerja auditor pada Kantor Akuntan Publik yang terdaftar di IAPI Cabang Bandung. Hasil ini mendukung penelitian Zaenal Fanani (2007) bahwa ketidakjelasan peran tidak berpengaruh signifikan terhadap kinerja auditor. Lalu Menurut Brief dkk dalam Amilih dan Rosita Dewi (2008) Ketidakjelasan peran (role ambiguity) adalah : "Role ambiguity atau ketidakjelasan peran adalah suatu kesenjangan antara jumlah informasi yang dimiliki seorang dengan yang dibutuhkannya untuk dapat melaksanakan perannya dengan tepat." Secara lebih spesifik lagi Zaenal Fanani dkk (2007) menyatakan bahwa kinerja auditor adalah: "kinerja auditor merupkan hasil kerja yang dicapai oleh seseorang dalam melaksanakan tugasnya, sesuai dengan tanggung jawab yang diberikan padanya dan menjadi salah satu tolak ukur yang digunakan untuk menentukan apakah suatu pekerjaan yang dilakukan akan baik ataukah sebaliknya". Dengan demikian ketidakjelasan peran bukan merupakan faktor penentu untuk meningkatkan kinerja auditor. Hal ini menunjukan bahwa ketidakjelasan peran yang muncul tidak menghambat dalam menyelesaikan tugas-tugas atau pekerjaaan auditor sehingga menurunkan kinerja mereka. 


\section{KESIMPULAN}

1. Struktur audit bepengaruh signifikan terhadap kinerja auditor. Hal ini menunjukan bahwa penggunaan struktur audit dapat membantu auditor dalam melaksanakan tugasnya menjadi lebih baik sehingga dapat meningkatkan kinerja auditor.

2. Konflik peran berpengaruh signifikan terhadap kinerja auditor. Hal ini menunjukan bahwa konflik peran yang merupakan suatu gejala psikologis yang dialami oleh auditor yang timbul karena adanya dua rangkaian tuntutan yang bertentangan sehingga menyebabkan rasa tidak nyaman dalam bekerja dan secara potensial bisa menurunkan motivasi kerja sehingga bisa menurunkan kinerja secara keseluruhan.

3. Ketidakjelasan peran tidak berpengaruh signifikan terhadap kinerja auditor. Hal ini menunjukan bahwa ketidakjelasan peran yang muncul tidak dapat menghambat dalam menyelesaikan tugas-tugas atau pekerjaaan auditor.

\section{REFERENSI}

Ahmad Aiwani. 2007. Pengaruh Kecerdasan Emosional Terhadap Kinerja Auditor Pada Kantor Akuntan Publik Di Kota Semarang, Penelitian. Fakultas Ekonomi Universitas Negeri Semarang, Semarang.

Amilih dan Rosita Dewi. 2008. Pengaruh Komitmen Organisasi Terhadap Kepuasan Kerja Akuntan Publik Dengan Role Stress Sebagai Variabel Moderating, JIAAI Vol 12.

Arens dan Loebbecke. 2003. Auditing (Pendekatan Terpadu), yang diadopsi oleh Amir Abadi Yusuf. Jakarta : Salemba Empat.

Arens. A. Alvins et. a1. 2003. Auditing Dan Pelayanan Verifikasi, (Pendekatan Terpadu) . Edisi 9, Alih bahasa Tim Dejacarta. Jakarta: Indeks.

Arikunto, Suharsimi. 2001. Prosedur Penelitian Suatu Pendekatan Praktek. Jakarta : Rineka Cipta.

Bamber, E. Michael, et. a1. 2003. Audit Structure And Other Determinants Of Audit Report Lag, An Empirical Analysis, Journal of Auditing Research, Volume 12.

Boynton, et.a1. 2001. Modern Auditing (Jilid 1). Edisi 7. Alih bahasa Paul A. Rajoe dkk. Jakarta : Erlangga.

Eka Murtiasri dan Imam Ghozali. 2006. Anteseden Dan Konsekuensi Burnout Pada Auditor: Pengembangan Terhadap Role Stress Model, Simposium Nasional Akuntansi 9.

Fanani, Zaenal. 2007. Pengaruh Struktur Audit, Konflik Peran dan Ketidakjelasan Peran Terhadap Kinerja Auditor. Universitas Airlangga.

Fisher, Richard T. 2001. Role Stress, The Type A Behavior Pattern, And External Auditor Job Satisfaction And Performance, Journal of Behavioral Research In Accounting, Volume 13.

Gibson, et.a1. 2003. Dalam Organisasi dan Manajemen. Alih bahasa oleh Djoerban Wahid. Jakarta: Eirlangga.

Hansiadi Yuli Hartanto dan Indra Wijaya Kusuma. 2001. Analisis PengaruhvTekanan Ketaatan Terhadap Judment Auditor. JAM Vol 12, STIE YKPN.

Hasibuan, Malayu S. P. 2006. Manajemen Sumber Daya Manusia. Jakarta: Bumi Aksara.

Husein Umar. 2003. Evaluasi Kinerja Perusahaan Cetakan 2, Jakarta : Gramedia

Pustaka Utama. 2003. Metode Riset Akuntansi Terapan. Jakarta : Ghalia Indonesia.

Hudayati, Ataina. 2002. Perkembangan Penelitian Akuntansi Keprilakuan : Berbagai Teori, Jurnal Akuntansi dan Auditing Indonesia. Vol 6 No. 2 
Imam Ghozali. 2006. Analisis Multivariate dengan Program SPSS. Semarang: Badan Penerbit UNDIP.

J. Winardi. 2004. Manajemen Perilaku Organisasi, Jakarta : Prenada Media. Mardiasno, 2002. Akuntansi Sektor Publik, Penerbit Andi, Yogyakarta.

Moh Nazir. 2009. Metode Penelitian, Jakarta. Ghalia Indonesia. Mulyadi. 2002. Auditing, Edisi 6. Jakarta : Salemba Empat.

Robbins, P. Stephen., dan A. Timothy. 2008. Judge Perilaku Organisasi (Organizational Behavior), Edisi 12. Alih bahasa Diana Angelica dkk. Jakarta : Salemba Empat.

S. Nitisemitro, Alex. 2000. Manajemen. Sumber Daya Manusia Perusahaan, Bandung: PT. Remaja Rosda Karya.

S. Siswanto Sastro Hadiwiryo. 2002. Manajemen Tenaga Kerja Indonesia, Jakarta: Erlangga.

Saludin Muiz. 2007. Pemikiran Teori Organisasi dan Manajemen Antara Sun Tzu dan Kini, Jakarta : Graha Ilmu.

Siti Rahayu dan Ely Suhayati. 2010. Auditing (Konsep Dasar dan Pedoman Pemeriksaan Akuntan Publik), Yogyakarta : Graha Il 